\title{
Influence of tow duration and tooth length on the number of damaged razor clams Ensis siliqua
}

\author{
Miguel B. Gaspar ${ }^{1, *}$, Margarida Castro ${ }^{2}$, Carlos C. Monteiro ${ }^{1}$ \\ 'Instituto de Investigação das Pescas e do Mar, Centro Regional de Investigaçāo Pesqueira do Sul, Avenida 5 de Outubro s/n, \\ P-8700 Olhào, Portugal \\ ${ }^{2}$ Universidade do Algarve, Unidade de Ciências e Tecnologias dos Recursos Aquáticos, Campus de Gambelas, P-8000 Faro, Portugal
}

\begin{abstract}
The incidence of shell damage due to dredging was studied in the bivalve Ensis siliqua off Lagos, on the south coast of Portugal. Three tow durations (1,3 and $5 \mathrm{~min})$ and 2 tooth lengths $(30$ and $40 \mathrm{~cm}$ ) were investigated. Both factors affected the proportion of damaged individuals. The increase of tooth length results in lower proportions of damaged razor clams. An increase in tow duration increased total numbers caught but also increased the proportion of damaged clams. It is suggested that dredges with $40 \mathrm{~cm}$ teeth and tows of $1 \mathrm{~min}$ duration should be used in this fishery, although experiments should be undertaken in order to evaluate the environmental and ecological impact of dredges.
\end{abstract}

KEY WORDS: Dredge - Ensis siliqua - Indirect mortality Bivalve

Fishing mortality has non-yield or indirect components, which may be significant in some dredge fisheries (Needler \& Ingalls 1944, Arntz \& Weber 1970, Gruffydd 1972, Gwyther \& MacShane 1988). In fact, apart from the commercial catch, dredges also cause mortality both during the fishing operation and on board due to rough handling or exposure time on deck of undersized specimens. In the Portuguese bivalve fishery little or no damage occurs to solid-shelled bivalves, such as Spisula solida, Venus striatula and Donax trunculus, due to the dredge (Gaspar 1996). The negative impact caused by the passage of the dredges over the beds of these species is more likely to affect other non-commercial species. On the other hand, in the Ensis siliqua fishery, damage is caused by the dredge because of this species' thin shell. This paper reports observations of the effects of the tow duration and the tooth length on the incidence of shell damage inflicted by dredging on this species.

\footnotetext{
•E-mail: mbgaspar@ip.pt
}

Materials and methods. The experiment was done in July 1995 in a site off Lagos, southern Portugal, at approximately $10 \mathrm{~m}$ depth. Two dredges with similar structure and mesh size (35 mm) but with different tooth lengths $(30$ and $40 \mathrm{~cm}$ ) were towed side by side. The dredges were typical of those used in the fishery (Fig. 1). Three tow durations of 1,3 and 5 min were investigated. A total of 30 hauls were completed, 10 of each tow duration. For each tow and dredge the catch was weighed and the number of damaged and undamaged razor clams counted. Razor clams were classified as damaged if they were already dead or if the level of damage (i.e. shell damage) would almost certainly result in their subsequent death. Specimens with minor damage, such as chipped shell margins, were treated as undamaged.

A $\chi^{2}$-test for comparison of overall proportions (Fleiss 1981) was used to test the effect of tow duration and tooth length on the proportion of damaged shells. The

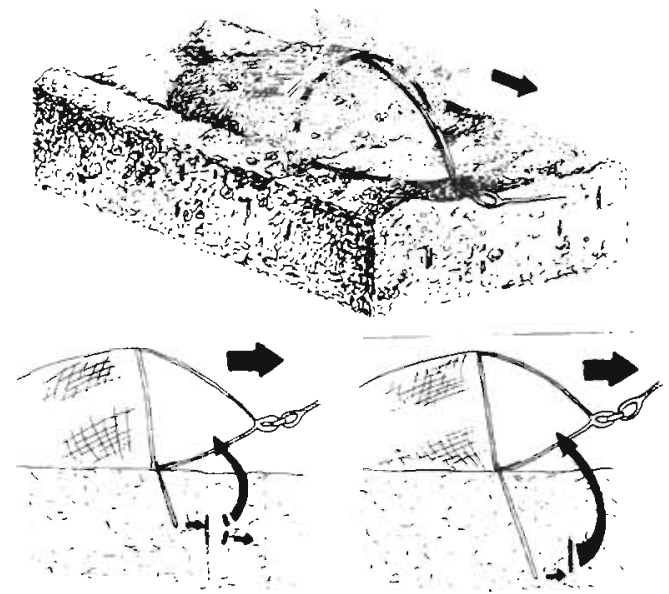

Fig. 1. Scheme showing the effect of tooth length on the number of damaged razor clams 
Table 1. Statistics for combined data of 10 tows for each duration and tooth length: mean number caught per tow, standard error and $95 \%$ confidence level for numbers caught per tow and overall percent of damaged indivaduals

\begin{tabular}{|lccc|}
\hline & \multicolumn{4}{c|}{ Tow duration } \\
& $1 \mathrm{~min}$ & $3 \mathrm{~min}$ & $5 \mathrm{~min}$ \\
\hline $30 \mathrm{~cm}$ tooth length & & & \\
Mean number & 36.5 & 93.8 & 132.3 \\
Standard error & 5.25 & 8.87 & 17.69 \\
Contidence level $(95 \%)$ & 11.88 & 20.07 & 40.02 \\
Proportion damaged & 0.30 & 0.51 & 0.60 \\
40 cm tooth length & & & \\
Mean number & 31.5 & 63.6 & 118.3 \\
Standard error & 2.42 & 6.46 & 9.78 \\
Confidence level $(95 \%)$ & 5.47 & 14.62 & 22.13 \\
Proportion damaged & 0.12 & 0.24 & 0.22 \\
\hline
\end{tabular}

effect of tow duration was compared within each tooth length and the effect of tooth length was tested within each tow duration.

Results. All comparisons were significant at the 0.001 level. $\chi^{2}$ values of the test statistic for different durations within each tooth length were 288.2 and 288.3 for 30 and $40 \mathrm{~cm}$ respectively, and the $\chi^{2}$ values for different tooth lengths within each tow duration were $30.3,110.3$ and 363.5 for 1,3 and 5 min durations respectively. Thus, an increase in tow duration increases the proportion of damaged individuals.

Descriptive statistics are presented in Table 1. For the same tow duration 2 to 3 times fewer razor clams were damaged when $40 \mathrm{~cm}$ long teeth were used.

Discussion. The study shows that tooth length and tow duration affect the number of damaged razor clams Ensis siliqua. An increase in the tooth length results in lower proportions of damaged razor clams. In a resting situation, without perturbation, this species burrows close to the surface, with its siphon sticking out of the sediment. When it feels any perturbation, it burrows deeper in the sediment in a defensive response. In situ observations using a probe showed that they can burrow as deep as $60 \mathrm{~cm}$ below the surface. It is thought that this defensive behaviour occurs during fishing. Thus, longer dredge teeth penetrating the bottom deeper allow $E$. siliqua to be caught below the lower edge of the shell, lifting the razor clams into the dredge without causing damage. In contrast, when shorter teeth are used, the teeth hit a higher number of razor clams, leading to more damage to the shell (Fig. 1). These results suggest that a similar effect should occur with clams that are in contact with but are not caught by the dredge (non-catch mortality). It is also expected that in this group, shorter teeth will cause a higher proportion of damaged shells, and consequently higher mortality.
For all 3 tow durations it was observed that dredges with $30 \mathrm{~cm}$ teeth caught a higher number of razor clams than those with $40 \mathrm{~cm}$ teeth. In situ observations by divers showed that this is the result of the dredge with $30 \mathrm{~cm}$ teeth covering a wider area than the dredge with $40 \mathrm{~cm}$ teeth. Since the 2 dredges are towed side by side, the $40 \mathrm{~cm}$ tooth dredge is subjected to higher resistance from the sediment, resulting in a rotation of the boat leaving the $30 \mathrm{~cm}$ dredge in the outside trajectory, therefore dredging a larger area. This does not correspond to a more efficient catch, since the proportions of damaged shells is higher with $30 \mathrm{~cm}$ teeth. As a consequence, the dredge with $40 \mathrm{~cm}$ teeth proved more efficient, catching a larger number of razor clams in good condition. This was particularly so in the tows lasting $5 \mathrm{~min}$. In a real life situation, fishing boats using 2 dredges always use teeth of the same size

Needler \& Ingalls (1944) and Medcof \& MacPhail (1964) reported that approximately $50 \%$ of the undersized clams (Mya arenaria) that remained in the sediment after the passage of the gear died as a result of the harvesting process either by breakage or smothering. Several authors have studied the negative impact of dredges on bivalve populations by comparing the mortality in exploited and non-exploited areas. Gwyther \& McShane (1988) estimated the natural mortality rate for unfished populations of Pecten fumatus as $0.52 \mathrm{yr}^{-1}\left(0.04 \mathrm{mo}^{-1}\right)$ while McLoughlin et al. (1991) estimated the post-fishing mortality rate as $0.28 \mathrm{mo}^{-1} ;$ times the mortality rate estimated by Gwyther \& MacShane (1988). Arntz \& Weber (1970) found soft parts of Artica islandica in the stomachs of cod Gadus morhua, and as cod themselves are not able to break the shell of A. islandica, they concluded that the fish fed on clams when their shells were broken by otterboards. Gruffydd (1972), in a series of laboratory experiments on post-fishing mortality of Pecten maximus, demonstrated that scallops damaged by the dredge were 13 times as likely to die compared with undamaged ones. Similar observations were made by Naidu (1988), who reported that 4 to 8 times more Chlamys islandica died from fishing-related causes than from natural causes. We believe that the high post-fishing mortality is related to the low catching efficiency of the gears used in these fisheries. In this context, catching efficiency is considered to be the ratio between the number of razor clams entering the dredge and the number of razor clams in the dredge path. Our results show that damage to razor clam stocks is inversely proportional to catching efficiency. This is in agreement with the findings of McLoughin et al. (1991), who stated that the number of damaged individuals is directly related to the catching efficiency. They found that the low catching efficiency of the scallop dredge (15\%) used to 
catch $P$. fumatus was responsible for crushing and damaging 4 to 5 times more scallops than the number landed.

The overall results of this work suggest that the 2 effects studied, tooth length and tow duration, are only important with respect to proportion of damaged shells. From the management point of view, shorter tows with longer teeth should be adopted in the Ensis siliqua fishery. Such measures would benefit the fishermen since they would increase their yield and profit because of the smaller number of damaged individuals caught.

A gear with the characteristics of the ones used in this work catches roughly half of the individuals below the minimum landing size of $100 \mathrm{~mm}$. This problem should be addressed in relation to other characteristics of the gear, not studied here, such as tooth spacing and mesh size. The knowledge that this species can burrow to depths greater than $40 \mathrm{~cm}$ suggests that experiments with dredges with teeth longer than this, up to $60 \mathrm{~cm}$, should be undertaken, to verify if proportions of damaged individuals can be reduced further.

The impact of the dredge must also be considered in relation to sediment perturbation and the benthic community. With regards to the sediment, the impact of the dredge is not known. The target species of this fishery only inhabits clean sandy bottoms at depths between the 5 and $13 \mathrm{~m}$. These areas are influenced by tidal action and currents, and are free of toxic materials. Therefore, the physical impact of the dredge is likely to have only a short duration following the passage of the dredge. These aspects were discussed within the ICES with similar conclusions (Anon. 1988). Direct observations showed that, in this kind of sediment, the dredge tracks are erased in less than $24 \mathrm{~h}$.

The effects on the benthic community are not known. This species is caught with other bivalves such as Acanthocardia tuberculata, Ensis ensis, Mactra coralina, Mactra glauca, Pharus legumen, Tellina crassa and Venus striatula. Overall, the by-catch of other bivalves represents roughly 10 to $15 \%$ in numbers. Apart from these, other species caught include crabs, hermit crabs, brittle stars and polychaetes. The community structure in these areas prior to fishing activity is not known and closed areas do not exist on the south coast of Portugal for this fishery. Therefore, right now, an understanding of the effect of dredging in these areas is not possible, but efforts should be made in the future. Studies done in other areas suggest that continuous dredging leads to a change in the community structure, favouring species that are relatively immune to disturbances by dredge, and reduces the

Editorial responsibility: Otto Kinne (Editor), Oldendorf/Luhe, Germany abundance of species less tolerant (long-lived species) to these same effects (Hall et al. 1990, Anon. 1991). A switch to dredges with"longer teeth, as suggested in the present study, may decrease mortality on all the other bivalve species, while alteration effects on the epifauna are not known. The effects of the dredge can only be correctly evaluated if one compares the before and after exploitation composition of the community. Since areas restricted to fishing do not exist in this region, and all known beds are exploited, such an experiment is not possible at this moment. The authors strongly suggest that a restricted area should be defined in order to allow the study of the effects of this gear on the environment.

Acknowledgements. We thank Dr Karim Erzini for reviewing the manuscript and 3 anorymous referees whose suggestions greatly improved this work. We are indebted to the crew of N/I 'Donax' and the staff of Centro Regional de Investigaçào Pesqueira do Sul for their assistance in collecting the material. M.B.G. was funded by Junta Nacional de Investigação Científica e Tecnológica-Programa CIÊNCIA and PRAXIS XXI.

\section{LITERATURE CITED}

Anon. (1988) Report of the Study Group on the effects of bottom trawling. CM 1988/B:56

Anon. (1991) Report of the Study Group on ecosystem effects of fishing activities. CM 1991/G:7

Arntz WE, Weber W (1970) Cyprina islandica L. (Mollusca, Bivalvia) als Nahrung von Dorsch und Kliesche in der Kieler Bucht. Ber Dtsch Wiss Komm Meeresforsch 21: $193-205$

Fleiss JL (1981) Statistical methods for rates and proportions. John Wiley \& Sons, New York

Gaspar MB (1996) Bivalves do litoral oceânico algarvio. Aspectos da biologia, ecologia e da pescaria dos mananciais de interesse económico: aplicaçào à gestão dos recursos. PhD thesis, Universidade do Algarve, Faro

Gruffydd LL (1972) Mortality of scallops on a Manx scallop bed due to fishing. J Mar Biol Assoc UK 52:449-445

Gwyther D. MCShane PE (1988) Growth rate and natural mortality of the scallop (Pecten alba) Tate in Port Phillip Bay, Australia, and evidence for changes in growth rate after a 20 year period. Fish Res 6:347-361

Hall SJ, Basford DG, Robertson NR (1990) The impact of hydraulic dredging for razor clams Ensis sp. on an infaunal community. Neth J Sea Res 27:119-125

McLoughlin RJ, Young P, Martin R, Parslow J (1991) The Australian scallop dredge: estimates of catching efficiency and associated indirect fishing mortality. Fish Res 11:1-24

Medcof JC, MacPhail JS (1964) Fishing efficiency of clam hacks and mortalities incidental to fishing. Proc Natl Shellfish Assoc 58:53-72

Naidu KS (1988) Estimating mortality rates in the Iceland scallop, Chlamys islandica (O.F. Muller). J Shellfish Res 7:61-71

Needler AWH, Ingalls RA (1944) Experiments in the production of soft-shelled clams ( $\left.M \gamma^{\prime} a\right)$. Fish Res Bd Can, Atl Prog Rep 35:3-8

Submitted: February 16, 1998; Accepted: May 29, 1998

Proofs recelved from author(s): July 13, 1998 